\title{
NOTE.
}

\section{A NOTE ON AN ABNORIMALITY IN THE STEM OF HELIANTHUS}

ANNUUS.-The stem of the Sunflower has been the subject of such frequent detailed examination that it is surprising that so few cases of abnormal structure have been recorded. This is also the case with many other plants which have been selected as types for laboratory work. In the course of such treatment large quantities of material are cut up and examined, with the result that every opportunity is provided for gaining a knowledge of the range of variety of structure. The uniformity of the results of such examinations serves only to emphasize the remarkable constancy with which the typical structure is maintained.

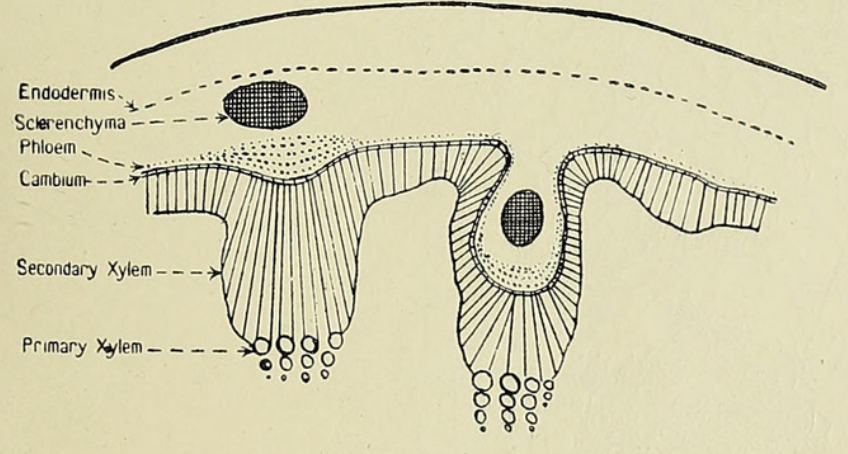

A

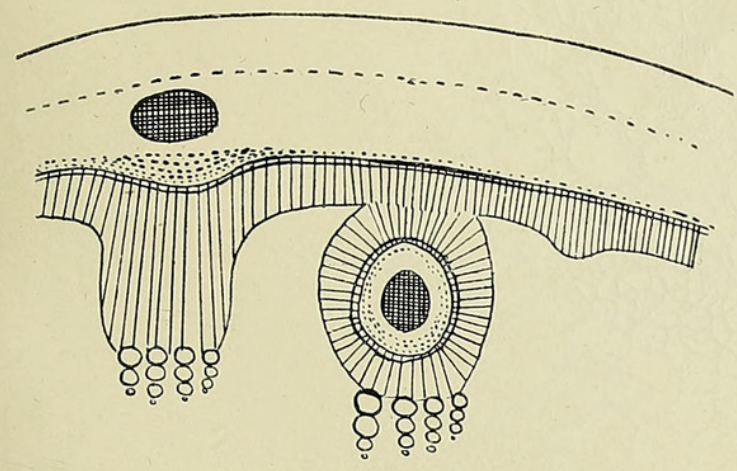

$\mathrm{C}$

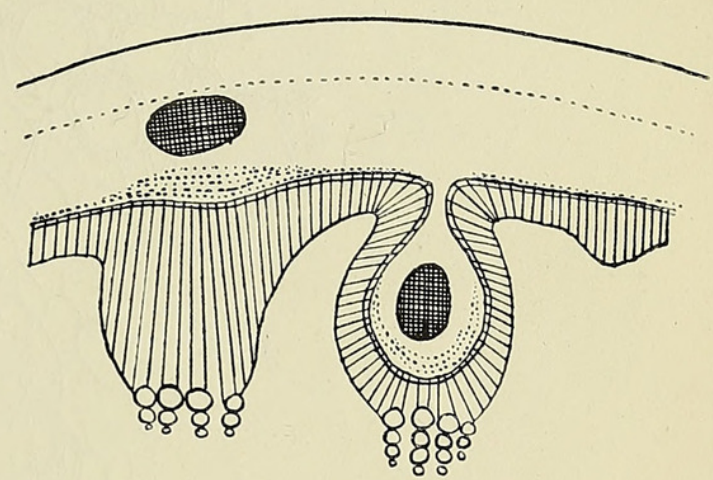

B

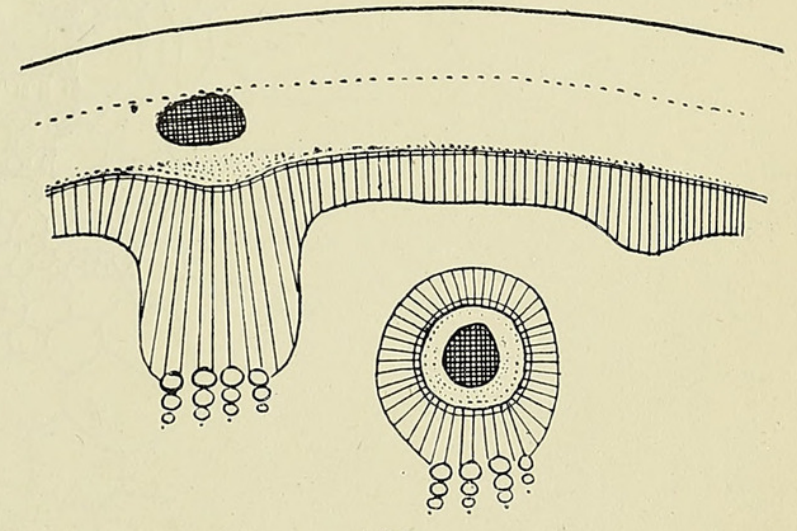

$\mathrm{D}$

FIG. I.

The particular variation in structure met with in this instance was found in a short length of stem taken from a young plant of Helianthus anmuus.

Unfortunately only a small portion of the material showing the abnormality was found, and it did not include a node. However, there were sufficient differences in structure between the two ends of the specimen to suggest a possible explanation of the mode of origin of the peculiarities about to be described.

[Annals of Botany, Vol. XXX. No. CXIX. July, I9ı6.] 
Two distinct abnormalities were presented by the specimen : bundles.

I. A deviation from the normal longitudinal course of one of the leaf-trace

2. A development of secondary vascular tissues in connexion with the displaced bundle resulting in the formation of a concentric bundle.

I. A reference to the diagrams (Fig. I) illustrating the series of sections taken through the length of the material under examination will show that one of the

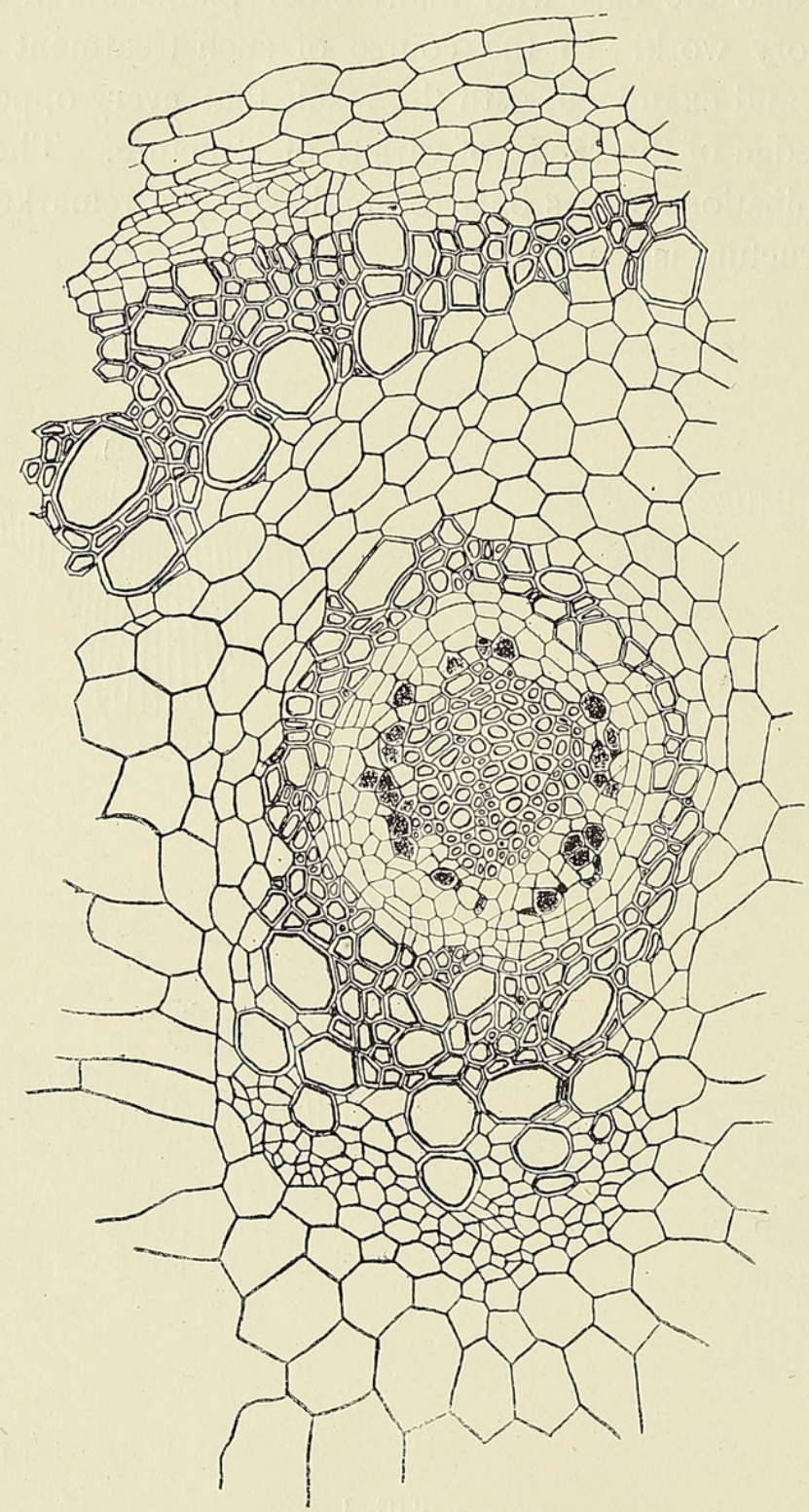

FIG. 2 .

bundles of the normal vascular ring, presumably a leaf-trace bundle, departs somewhat from the typical course.

Instead of taking a vertical direction parallel to the neighbouring bundles, it passes obliquely downwards and inwards until it is in the pith, completely separated from and interior to the other vascular strands.

How far this abnormal course is continued it is impossible to say, owing to the 
lack of material, but it may be presumed that the bundle eventually returns to the periphery and establishes connexions with the neighbouring bundles at some node below.

The course of this bundle suggests, to some extent, that taken by the leaf-traces in some members of the Piperaceae, where, it will be recalled, the leaf-trace bundles form a system of medullary bundles during a part of their course in the stem.

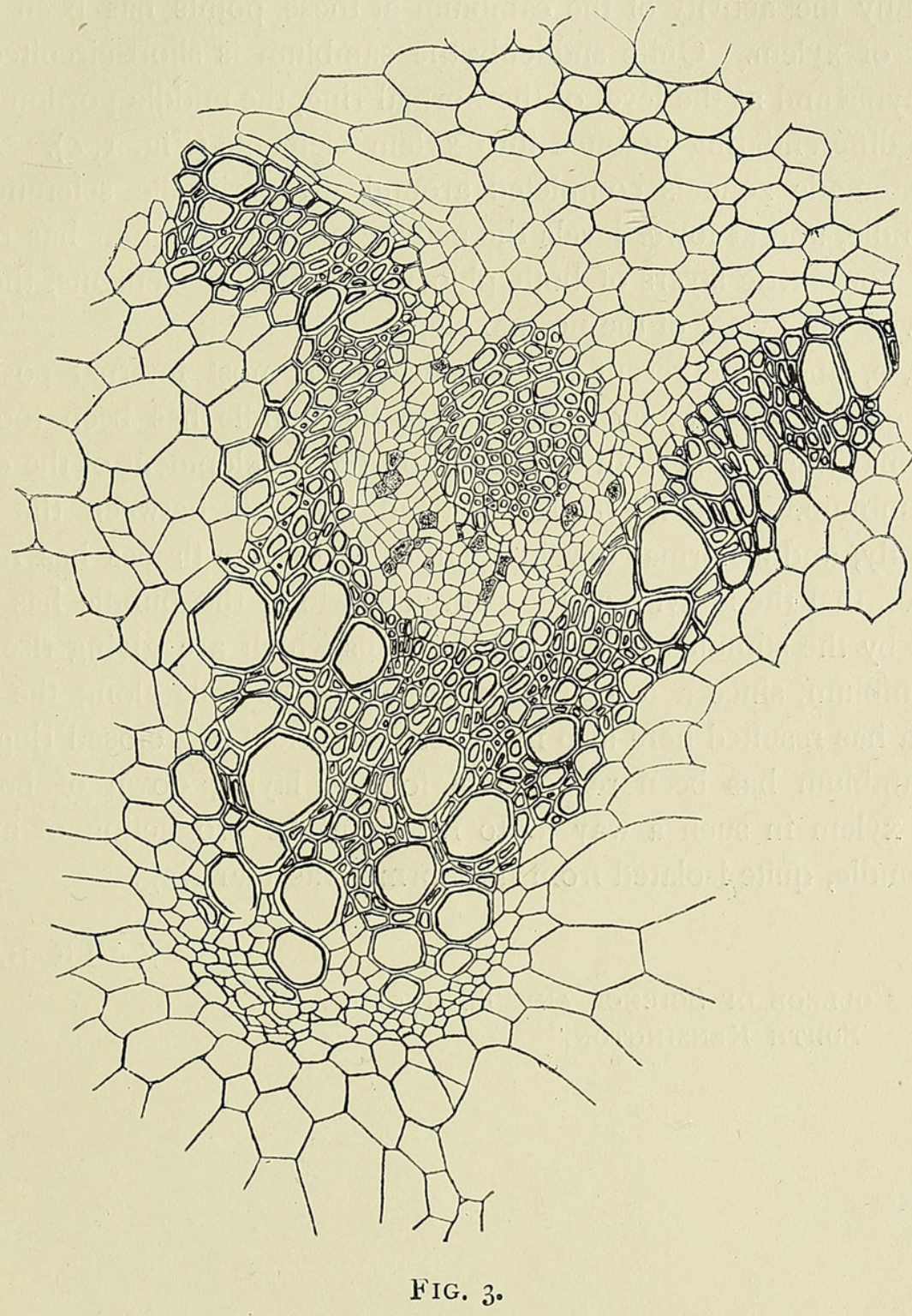

It is not suggested that the anomalous bundle in Helianthus traverses a complete internode before passing into the pith, as is the case for example in Peperomia.

2. The development of secondary tissue in the vascular ring in the neighbourhood of the abnormal bundle is of considerable interest.

A relatively small number of secondary elements have been laid down, and consequently there has been very little displacement of the primary tissues (Figs. 2 and 3 ). A reference to the diagrams in Fig. I will make clear the sequence of events.

At the stage illustrated in Figs. I, A, and 3, the bundle is not far removed from the 
normal ring, and the interfascicular cambium has developed between the bundles, and has consequently taken a somewhat sinuous course in this region.

In successive sections this sinuous course becomes more pronounced, the interfascicular cambium taking a radial course and passing along the flanks of the sclerenchyma (Fig. I, B). The further removal of the bundle from the normal ring leads to closer approximation of the horns of the $U$-shaped band of cambium, until they are separated by no more than two or three intervening cells.

Apparently the activity of the cambium at these points has been limited to the development of xylem. Quite suddenly the cambium is short-circuited both above the sclerenchyma and at the level of the normal ring, the middle portion and the intervening cells differentiating at once into xylem elements (Fig. I, c). As a result of this, a meristematic zone is completed around the pericyclic sclerenchyma of the displaced bundle, and at lower levels the activity of this cambium has resulted in the formation of concentric layers of both phloem and xylem elements, the latter being continuous with the xylem of the normal ring.

Figs. I, D, and 2 represent the bundle in its most internal position, and an examination of Fig. 2 shows clearly that here the bundle has been too far removed from the normal ring to exert any influence on the development of the ordinary interfascicular cambium. The latter has bridged the gap between the neighbouring bundles directly, and a normal development of secondary tissues has resulted. It is clear, however, that the activity of the cambium within the bundle has not remained uninfluenced by the stimulus of the dividing cells which are giving rise to the interfascicular cambium, since a formation of meristematic cells along the flanks of the sclerenchyma has resulted here also in the establishment of a closed ring of cambium.

This cambium has been responsible for the laying down of both secondary phloem and xylem in such a way as to result in the production of an amphivasal concentric bundle, quite isolated from the normal vascular ring.

KATE BARRATT.

Imperial College of Science and Technology, South Kensington. 


\section{$2 \mathrm{BHL}$ Biodiversity Heritage Library}

Barratt, Kate. 1916. "A note on an abnormality in the stem of Helianthus annuus." Annals of botany 30, 481-484.

https://doi.org/10.1093/oxfordjournals.aob.a089617.

View This Item Online: https://www.biodiversitylibrary.org/item/237452

DOI: https://doi.org/10.1093/oxfordjournals.aob.a089617

Permalink: https://www.biodiversitylibrary.org/partpdf/320134

\section{Holding Institution}

Smithsonian Libraries

\section{Sponsored by}

Biodiversity Heritage Library

\section{Copyright \& Reuse}

Copyright Status: Not in copyright. The BHL knows of no copyright restrictions on this item.

This document was created from content at the Biodiversity Heritage Library, the world's largest open access digital library for biodiversity literature and archives. Visit BHL at https://www.biodiversitylibrary.org. 